\title{
Common Traits of the Best Online and Face-to-face Classes: Evidence from Student Surveys
}

\author{
Rebecca A. Glazier \\ University of Arkansas at Little Rock \\ raglazier@ualr.edu \\ Heidi Skurat Harris \\ University of Arkansas at Little Rock \\ haharris@ualr.edu
}

Increasingly, college students are taking a mix of course modalities, enrolling in both online and face-to-face classes. Similarly, many college instructors are teaching both online and face-to-face classes. What are the key similarities and differences in quality instruction across these formats? Instructors can benefit from knowing what the best online and the best face-to-face classes have in common, and how to adjust their teaching to best fit the medium of delivery. We surveyed 2,007 undergraduate students at a public, metropolitan university and asked them about the best and worst classes they have ever taken. The resulting qualitative and quantitative data reveal some important consistencies across modalities-like effective communication and instructor availability. Other factors, however, differ by course format. Instructors seem to matter more in face-to-face courses, where they can establish personal relationships with students, whereas assignments are more important in online classes. Our findings can help college instructors in any modality reach students with the kind of instruction they will remember as truly excellent.

Keywords: online, face-to-face, teaching, retention, rapport, surveys

Paper presented at the American Political Science Association Teaching and Learning Conference, Albuquerque, New Mexico, February 7-9, 2020 
Online classes are now a mainstream part of higher education, with over $30 \%$ of all college students in the United States enrolled in at least one online class (Allen and Seaman 2017, Ortagus 2017). These classes include diverse course offerings ranging from self-paced, asynchronous learning modules to highly interactive, synchronous discussion-based classes. Online class size and delivery models also vary, from small, graduate-level courses much like traditional graduate classes to MOOCs (massive open online courses) ranging in the 1000s (Chingos et al. 2017). Students often take a mixture of courses in both modalities; rarely are students fully online or face-to-face (Jaggars 2014, Murphy and Stewart 2017, Lederman 2018, Glazier et al. 2019). As instructors adapt to a world of higher education where online learning is increasingly part of the student experience, how much of what we know about teaching in faceto-face classes transfers to the online environment?

In order to explore the similarities and differences between face-to-face and online classes from a student perspective, we surveyed 2,007 students at the [university redacted], a major metropolitan university, to ask them about the best and worst classes they have taken at that university. With $58 \%$ of students at [university redacted] taking at least one online class, the resulting data contained responses about both online and face-to-face "best" classes and online and face-to-face "worst" classes. These data make it possible to answer the following questions: What elements of the classroom, teacher, and learning experience contributed to students indicating that a class was the "best" or "worst" class? In what ways are the best online classes different from the best face-to-face classes?

The answers to these questions inform teaching in both online and face-to-face classes. The data reveal that some elements of good teaching are consistent across modalities. Effective communication and instructor availability are important to students no matter whether a course takes place in person or online. Other factors, however, differ by course format. For instance, the instructor's attitude and perceived enthusiasm were more important in face-to-face classes, whereas the instructor's engagement and course assignments were more important in online classes. These data indicate that in order to provide courses that students respond positively towards, and presumably stay enrolled in, instructors need to consider carefully the constraints imposed by different course modalities.

\section{The Puzzle of Online Retention}

Online higher education has grown a remarkable amount in recent years. The number of students taking online courses increased 17.2\% from 2012 to 2016 alone (Seaman, Allen, and Seaman 2018, 12), a statistic made even more remarkable by the fact that national annual college enrollments are down about 10\% over the same time period (Snyder, de Brey, and Dillow 2019). Nearly every major university in the United States today offers some online courses (Bowers and Kumar 2015, Capra 2011).

Yet, as online programs have grown in popularity in recent decades, a slow realization has begun to dawn on online instructors and programs: our online students are struggling. The success and retention of students taking online classes is often significantly lower than students taking face-to-face classes. Fewer students persist in online courses than in traditional classrooms, with attrition in online classes reaching as high as 50\% (Carr-Chellman and Duchastel 2000, Levy 2007, McLaren 2004, Tello 2007). Across differences in course and program type, students in online courses consistently drop their classes at higher rates (Jaggars 2014, Glazier 2016, Patterson and McFadden 2009, Bolsen, Evans, and Fleming 2016). 
While overall retention and completion of college degrees can be improved by the availability of online courses (Glader 2013), individual courses themselves still face higher attrition rates than their face-to-face counterparts, making online courses a major hurdle in the success of our students.

Why do online courses have such consistently lower retention rates? On the surface, technology and its use is the most obvious difference between online and face-to-face courses. For those faculty teaching online unprepared, technology can be a significant impediment to effective online teaching (Magda, Poulin, and Clinefelter 2015). When technology is used well, on the other hand, it can positively impact student engagement, making students more likely to respond positively to academic challenges, active and collaborative learning, student-faculty interaction, and generally making for a more supportive campus environment (Chen, Guidry, and Lambert 2009).

However, when technology is not just a tool, but the only way to communicate with the instructor and other students in the class, a very high level of transactional distance is created (Moore 2013). Low online retention rates are explained in part by the potentially high barrier to contact and relationship-building between faculty and students in online courses. Online rapport has only recently begun to be defined (Murphy and Rodríguez-Manzanares 2012), measured (Lammers and Gillaspy Jr. 2013), and evaluated (Sher 2009, Kanasa 2017, Kupczynski et al. 2010), but it appears to be more difficult to create rapport in online classes than in face-to-face classes. In a study of community college students, Jaggars (2014) finds that face-to-face courses have better peer-to-peer and student-instructor interaction than online courses, and the students preferred to take more important or difficult courses face-to-face (Jaggars 2014).

It's not just students that prefer the teaching and learning environment in face-to-face classes. Faculty recognize that building relationships with students in online classes can be more time-consuming (Aquila 2017, Worley and Tesdell 2009). And sometimes those efforts are not rewarded. For instance, Preisman (2014) demonstrated that the additional time spent in developing instructor presence through video lectures, audio feedback, and increased discussion board participation did not lead to significant gains in student grades or course evaluations. Skurat Harris et al. (2019) find that students often lack understanding of how tools such as discussion boards and videos connect to writing instruction in online courses. They found that students were most satisfied when provided direct feedback from faculty, compared to engaging in either discussion boards or peer review activities. In short, immediacy is simply harder to create in an online environment (Preisman 2014), and faculty who are unprepared for engagement in online classes may struggle to fully connect with students.

This research seeks to further understand the benefits of and barriers to student satisfaction with online classes. While satisfaction is only one element in a complex web of factors related to online learning success (Gering et al. 2018), the tendency towards lower retention rates in online classes means that instructors need to understand how to teach online classes as effectively as possible so that students will want to stay in them. Students have different expectations for different course formats, and we expect to see these come through when we ask students about their best and worst course experiences.

In asking students about the best and worst classes they had ever taken, we are hoping to find insights into the puzzle of online retention. What are the differences between the best online and the best face-to-face classes? Are the worst online classes worse than the worst face-to-face classes? 
Drawing on the literature that identifies online retention as a significant problem, building rapport in online classes as a challenge for many instructors, and the transactional distance of online courses as one of their major impediments, we expect that the most important difference between online and face-to-face classes is the distance between the instructor and the student. In face-to-face classes, students personally interact with the instructor on a regular basis, are more likely to develop a relationship with the instructor, and are more likely to experience both formal and informal opportunities for human connection. Because these opportunities are less common in online classes, the responses students give to our survey questions will also be significantly different.

Specifically, given the key difference of distance between the instructors and students in online classes, we posited three hypotheses:

Hypothesis 1: Online courses will be less likely to be considered "best" courses.

Hypothesis 2: Instructors will be more important for "best" course designation in face-toface courses, compared to online courses.

Hypothesis 3: Students who emphasize the instructor of the course will be more likely to designate the course as a "best" course.

\section{Methods}

In order to better understand how students view the differences between online and faceto-face classes, we surveyed graduate and undergraduate students at the [university redacted]. [University redacted] is a metropolitan university in the capital city of [state redacted] with an undergraduate and graduate student population at the time of the survey in Spring 2018 of 8,473. [University redacted] offers many online courses and 58\% of the student body was enrolled in at least one online class in Spring 2018. Thus, the educational profile at [university redacted] makes it an excellent university at which to examine the differences between online and face-toface classes.

After gaining approval from the University’s Institutional Review Board and access to the University's list of student email addresses, every student enrolled at [university redacted] in Spring 2018 received two email invitations: one to participate in a survey about the best class they have ever taken at [university redacted] and one to participate in a survey about the worst class they have ever taken at [university redacted]. A total of 2,007 students responded: 1,070 completed the survey about the worst class (making up 53.31\% of our total sample) and 937 completed the survey about the best class (46.69\% of our sample). The content of the two surveys was the same, with the best/worst language adjusted as needed. Students were allowed to complete both surveys but, due to confidentiality, we do not know how many did.

We included a number of variables to determine what leads a student to call a class the best or worst one they have ever taken. We were particularly interested in how student perceptions of the characteristics and actions of the instructor influenced their evaluations of a class. We measured these perceptions through a series of survey questions. Full question wording, summary statistics, and coding are available in the appendix in Table A1.

First, in order to measure student perceptions of instructor communication, we asked how much students agreed with the statement "the instructor communicates effectively with me" (coded on a Likert scale from 1 to 5). We also asked students what contributed the most to their evaluation of the course as the best/worst course and provided them with four forced-choice response options (interest in the subject; the instructor; the assignments, readings, and activities 
in the course; personal circumstances at the time they took the class). We created a binary variable for each of these response options. For instance, a binary variable for the instructor as the most important factor was created where those students who picked the instructor as the factor that most influenced the evaluation of the course as the best/worst were coded one, with all others coded zero.

In a separate question, we asked students to rank which was most important to their evaluation of a class as the best/worst: instructor relationship, instructor attitude, instructor engagement, and course organization. Students ordered the four options 1 to 4 , with numbers ranked higher (closer to one) indicating more importance.

We are also interested in how student perceptions of instructor availability might influence their evaluations of the class. We asked students about how available their instructor was to them when they had an issue through four possible modalities: in-person, in video conference, on the phone, and through email. These four were then summed into a single measure of instructor availability. Thus, a professor who was available through all four modalities would have a score of 4 , compared to a score of 1 for a professor who was only available through email.

We included a number of controls to account for the characteristics of the course. Most importantly, we asked students whether the course was taught face-to-face or online. We also asked students whether the class was in their major, whether the course was a university-required core course, the grade they earned (or expected to earn) in the course, and their interest in the subject of the course.

Beyond the course and the instructor, student characteristics could have influenced their selection of a class as best/worst. In terms of student demographic variables, we included gender, age, and race/ethnicity. We also included two student academic variables: their year in college (sophomore, junior, etc.) and their GPA. Question wording and summary statistics are provided in the Appendix in Table A1.

In both surveys, students were provided with space to write open-ended comments about the course. One-thousand, eight-hundred and fifty-one students (92.2\% of respondents) left open-ended comments. We wanted to capture the data provided by each individual thought students left in the open-ended comments, so we used sentence fragments as the units of analysis $(n=4,096)$. The qualitative answers were open and axial coded (Strauss and Corbin 1998) to develop categories with similar descriptive traits. Individual student comments were identified as being primarily about the course or about the instructor. Then, the comments were organized by phenomenon within those categories. Each unit was coded for both substance (e.g., enthusiasm, communication, etc.) as well as for tone (i.e., negative, neutral, or positive). The full code book is available from the authors upon request.

Open-ended comments were coded by both authors. A random subset of 75 responses were evaluated to determine inter-coder reliability (Cohen’s Kappa 0.857). Codes from the open-ended data included mentions of the instructor as caring, enthusiastic, engaged, and communicative.

\section{Results and Discussion}

What are the major differences that students saw between the best and worst classes? Is a bad online class significantly different from a bad face-to-face class? Is a good face-to-face class significantly different from a good online class? We turned first to quantitative data and 
difference of means tests to answer these questions. Armed with some initial quantitative results, we dig deeper into the qualitative data.

About $2 / 3$ of responding students $(1,376$ or $68.56 \%)$, choose to tell us about a face-toface class and about $1 / 3$ (631 or $31.44 \%$ ) chose to tell us about an online class. Of those who responded about a face-to-face class, 714 or $51.89 \%$ said it was the best and 662 (48.11\%) said it was the worst. For those telling about an online class, only 223 or $35.34 \%$ said it was a best class. The data indicate that fewer students chose online classes as the best classes they have ever taken, but students also talked about online classes less than face-to-face classes. The numbers are presented in Table 1.

Table 1. Student Respondent n by Course Designation (Best/Worst) and Medium (Face-toFace/Online)

\begin{tabular}{|c|c|c|c|}
\hline & Worst & Best & Total \\
\hline Face-to-Face & 662 & 714 & 1,376 \\
\hline Online & 408 & 223 & 631 \\
\hline Total & 1,070 & 937 & 2,007 \\
\hline
\end{tabular}

These data indicate that online classes were significantly less likely than face-to-face classes-35\% to 51\%--to be categorized as a best class, a finding supportive of Hypothesis 1. Students appeared to be more likely to pick face-to-face courses when they are thinking about really good courses. Yet, 23.79\% of all best classes chosen were online classes, not an insignificant number. Not as many students chose online classes when they think of really excellent classes - so good that students identify the class as the best one they have ever takenbut it is far from impossible. Almost 1,000 students chose to tell us about their best class and nearly a quarter of them picked an online class.

How are the best face-to-face and the best online classes similar and different? We compare them in Table 2 and find them fairly similar, with some important differences. Seven of the fourteen variables we measure in Table 2 show significant differences between the online and face-to-face classes that students called the best.

Table 2. Difference of Means Tests Comparing Best Face-to-Face Classes and Best Online Classes

\begin{tabular}{|l|l|l|l|l|}
\hline & Overall & $\begin{array}{l}\text { Face-to- } \\
\text { Face }\end{array}$ & Online & Difference \\
\hline \multicolumn{5}{|c|}{ Open-ended Responses on Instructor Characteristics } \\
\hline Caring & 0.18 & 0.2 & 0.12 & $0.08^{*}$ \\
\hline Engaged & 0.28 & 0.28 & 0.28 & 0 \\
\hline Enthusiastic & 0.09 & 0.11 & 0.03 & $0.08^{*}$ \\
\hline Communicative & 0.11 & 0.11 & 0.14 & 0.03 \\
\hline \multicolumn{5}{|c|}{ Survey Questions } \\
\hline Instructor Availability & 13.52 & 13.48 & 13.65 & 0.17 \\
\hline $\begin{array}{l}\text { Instructor Communicates } \\
\text { Effectively }\end{array}$ & 4.71 & 4.72 & 4.69 & 0.03 \\
\hline \multicolumn{7}{|l|}{ Which is the Most Important Factor in Best Class Selection } \\
\hline
\end{tabular}




\begin{tabular}{|l|l|l|l|l|}
\hline Interest in the Subject & 0.16 & 0.15 & 0.19 & 0.04 \\
\hline Personal Situation & 0.02 & 0.02 & 0.05 & 0.03 \\
\hline Instructor & 0.62 & 0.67 & 0.43 & $0.24^{*}$ \\
\hline Assignments & 0.14 & 0.1 & 0.27 & $0.17^{*}$ \\
\hline \multicolumn{5}{|c|}{ Comparative Rankings of Influences on Best Class Selection } \\
\hline Instructor Relationship & 2.72 & 2.64 & 3.03 & $0.39^{*}$ \\
\hline Instructor Attitude & 1.94 & 1.83 & 2.34 & $0.51^{*}$ \\
\hline Instructor Engagement & 2.36 & 2.41 & 2.16 & 0.25 \\
\hline Course Organization & 2.97 & 3.1 & 2.45 & $0.65^{*}$ \\
\hline $\mathrm{N}$ & & 714 & 223 & \\
\hline${ }^{*} \mathrm{p}<.05$ & \multicolumn{5}{|l|}{} \\
\hline
\end{tabular}

The means comparisons in Table 2 provided our first opportunity to evaluate Hypothesis 2 , that instructor characteristics matter more for face-to-face than online classes. In terms of the open-ended responses, students who selected a face-to-face class as the best were more likely to leave a comment mentioning the enthusiasm and the caring of the instructor. Engagement and communication — two behaviors that may be easier to convey electronically—were not significantly different. Additionally, and in the same vein, quantitative survey questions about the availability of the instructor and the instructor's communication were indistinguishable across course mediums. These findings provide mixed support for Hypothesis 2. It seems as though some instructor characteristics are more important for face-to-face classes, but not all.

We saw stronger support for $\mathrm{H} 2$ when it came to the reasons why a student selected a course as the best. Those who chose a face-to-face class were more likely to say the instructor was the most important factor in that selection. They were also significantly more likely to rank their relationship with the instructor and the instructor's attitude as more important in their choice of their best class. Those students who selected an online class as the best, on the other hand, were significantly more likely to say that assignments were the most important factor in their choice and they ranked course organization significantly higher than students who chose face-to-face classes.

In line with our theoretical expectations, these results indicated that it may be easier for instructors to connect personally with students in face-to-face classes. Their students noticed that relationship and the instructor's attitude, and it significantly influenced their evaluation of the course. In online classes, on the other hand, personal interactions were less common by definition. Assignments and course organization thus became more important and weighed more heavily as students evaluated the course.

What about the worst classes? How are the worst face-to-face and worst online classes similar and different? We conduct the same difference of means tests to compare the worst faceto-face and worst online classes in Table 3.

In Table 3 we can again evaluate $\mathrm{H} 2$ as we compared the importance of the instructor in the worst face-to-face classes and the worst online classes. We saw support for Hypothesis 2 once again as significantly more students in face-to-face classes mentioned caring in their openended responses, compared to the online classes. 
Table 3. Difference of Means Tests Comparing Worst Face-to-Face Classes and Worst Online Classes

\begin{tabular}{|c|c|c|c|c|}
\hline & Overall & $\begin{array}{l}\text { Face-to- } \\
\text { Face }\end{array}$ & Online & Difference \\
\hline \multicolumn{5}{|c|}{ Open-ended Responses on Instructor Characteristics } \\
\hline Caring & 0.15 & 0.19 & 0.09 & $0.1^{*}$ \\
\hline Engaged & 0.17 & 0.12 & 0.24 & $0.12 *$ \\
\hline Enthusiastic & 0.05 & 0.07 & 0.01 & 0.06 \\
\hline Communication & 0.18 & 0.18 & 0.17 & 0.01 \\
\hline \multicolumn{5}{|c|}{ Survey Questions } \\
\hline Instructor Availability & 8.81 & 8.816 & 8.818 & 0.002 \\
\hline $\begin{array}{l}\text { Instructor Communicates } \\
\text { Effectively }\end{array}$ & 2.58 & 2.583 & 2.581 & 0.002 \\
\hline \multicolumn{5}{|c|}{ Which is the Most Important Factor in Worst Class Selection } \\
\hline Interest in the Subject & 0.06 & 0.04 & 0.07 & 0.03 \\
\hline Personal Situation & 0.03 & 0.02 & 0.04 & 0.02 \\
\hline Instructor & 0.57 & 0.63 & 0.46 & $0.17 *$ \\
\hline Assignments & 0.27 & 0.21 & 0.36 & $0.15^{*}$ \\
\hline \multicolumn{5}{|c|}{ Comparative Rankings of Influences on Worst Class Selection } \\
\hline Instructor Relationship & 2.78 & 2.75 & 2.84 & 0.09 \\
\hline Instructor Attitude & 2.49 & 2.39 & 2.65 & $0.26 *$ \\
\hline Instructor Engagement & 2.34 & 2.45 & 2.16 & $0.29 *$ \\
\hline Course Organization & 2.37 & 2.33 & 2.39 & 0.06 \\
\hline $\mathrm{n}$ & & 662 & 408 & \\
\hline
\end{tabular}

Because we were talking about worst classes as opposed best classes, a "caring” mention in an open-ended comment almost certainly carries a very different meaning. Thus, it looks like the lack of a caring instructor contributes to worst class evaluations in face-to-face classes more than in online classes, just as the presence of a caring instructor contributes to best class evaluations in face-to-face classes more than in online classes. In both cases, the students noted caring (or its lack) more when they have personal contact with instructors through face-to-face classes. Thus, comparing Table 2 to Table 3 actually revealed an initial lack of support for Hypothesis 3. Instructors seemed to matter to students both when they are weighing the designation of a class as the best and when they were considering it the worst.

In support of H2, just as with the best classes, we saw a split in terms of the factors that matter most in student evaluations of the worst classes by modality. Students in the worst faceto-face classes were significantly more likely to say the instructor matters the most in their evaluation of the course, whereas students in the worst online classes say assignments matter the most. Engagement is also significantly different across course delivery modes in Table 3. Students in the worst online classes are more likely to mention instructor engagement (likely the lack of engagement) in their open-ended comments. We suspected that, just as students might be less likely to stay plugged into their online classes without the physical class meeting multiple times each week, instructors were likely to do the same. Importantly, students noticed when 
online instructors check out. Table 3 indicates that lack of instructor engagement contributes to the evaluation of an online class as the worst more so than in face-to-face classes.

In terms of rankings, we saw again that instructor attitude matters more in face-to-face classes_-perhaps because attitude is less easily communicated electronically. When it comes to the worst classes, however, course organization was not significantly different across modes as it was for the best classes. Instructor engagement is. This indicates that positive engagement didn't help in the best online classes any more than the best face-to-face classes, but a lack of instructor engagement seemed to hurt the worst online classes more than it hurt the worst face-to-face classes.

We know that additional factors influenced student evaluations of a course, so we ran a series of logit models with the binary best class designation as the dependent variable. The models considered whether the course was online, the grade the student earned in the course, whether the course was in their major or in the core of courses required by the university, how interested the student was in the course, how effectively the instructor communicated, and whether the instructor was selected as the most important factor in the choice of the course as either best or worst. We also included a number of academic and demographic controls, including year in college, gender, nonwhite race/ethnicity, age, and GPA.

The logit models made it possible to evaluate the relative influence of a number of variables simultaneously and to assess all three hypotheses. By including the online course modality variable, we could test H1, that online course were less likely to be considered "best" classes by students. By including instructor variables, we could test $\mathrm{H} 3$, that students who emphasize the instructor will be more likely to designate a course as the "best" class. We also ran separate models for just online and just face-to-face classes, so we could evaluate $\mathrm{H} 2$, whether instructors were more important for the "best" course designation in face-to-face courses compared to online courses.

Table 4. Logit Model of Best Class Designation

\begin{tabular}{|l|l|l|}
\hline Variable & Coeffecient & Odds Ratio \\
\hline Online Course & $-0.462(0.253)$ & \\
\hline Grade Earned & $0.795^{* * *}(0.105)$ & 2.214 \\
\hline Course is in Major & $-0.095(0.276)$ & \\
\hline Course is in the Core & $0.115(0.112)$ & \\
\hline Interest in Course & $0.698^{* * *}(0.112)$ & 2.010 \\
\hline Instructor Communicates Effectively & $2.326^{* * *}(0.136)$ & 10.241 \\
\hline Instructor is the Most Important Factor & $0.575^{* *}(0.232)$ & 1.778 \\
\hline Year in College & $-0.141(0.101)$ & \\
\hline Female & $-0.079(0.115)$ & \\
\hline Nonwhite & $-0.203(0.242)$ & \\
\hline Age & $-0.009(0.011)$ & \\
\hline GPA & $-1.078^{* * *}(0.273)$ & 0.339 \\
\hline Constant & $-10.641(0.810)$ & \\
\hline $\mathrm{N}$ & 1,403 & \\
\hline Pseudo R2 & 0.71 & \\
\hline & & \\
\hline
\end{tabular}


Note. standard errors are in parentheses. ${ }^{*} \mathrm{p}<.05,{ }^{* *} \mathrm{p}<.01,{ }^{* * *} \mathrm{p}<.001$

When all of these factors are analyzed together, five variables emerged as highly significant in determining whether a course was selected as the best course a student has taken at [university redacted]. In terms of the student characteristics, the grade they earned and their interest in the subject of the course were both highly significant. It is no surprise that students liked classes in which they were interested and made good grades. Additionally, students with high GPAs were less likely to designate a course as a best course. We can only speculate as to the reason here, but it may be that high-achieving students have higher standards for teaching excellence.

As far as our hypotheses go, Table 4 reveals, contrary to the expectations of Hypothesis 1 , online courses were not less likely to be named by the students as the best classes they have taken. Although fewer of the aggregate best classes were online classes, the statistical models take more factors into account, including the importance of the instructor, and do not show that course modality was a significant factor. Online classes were not inherently worse than face-toface classes or harder for students to like. Online courses are part of the mainstream of higher education and many students found excellent online instruction there.

As the odds ratios indicated, far and away the most important variable in the model of best course selection was effective communication. The strong impact of this variable was partially due to the question wording and the construction of the models. Instructor importance could have applied to either good or bad courses, but effective communication was likely to only be associated with good classes, so a stronger relationship in the model makes sense. This result also indicated just how important effective communication was to students, a message that was reinforced by the qualitative data. These findings support Hypothesis 3 and indicated that instructors matter a great deal to teaching excellence.

In order to directly compare those factors that influence the selection of a class as the best in an online versus a face-to-face modality, we ran the same logit models for both modalities separately. These models are presented side-by-side in Table 5.

Table 5. Logit Models of Best Class Designation by Course Modality

\begin{tabular}{|c|c|c|c|c|c|}
\hline \multicolumn{3}{|c|}{ Face-to-Face } & \multicolumn{3}{|c|}{ Online } \\
\hline Variable & Coeffecient & $\begin{array}{l}\text { Odds } \\
\text { Ratio }\end{array}$ & Variable & Coeffecient & $\begin{array}{l}\text { Odds } \\
\text { Ratio }\end{array}$ \\
\hline Grade Earned & $\begin{array}{l}0.991 * * * \\
(0.163)\end{array}$ & 2.488 & Grade Earned & $\begin{array}{l}0.766^{* * *} \\
(0.153)\end{array}$ & 2.152 \\
\hline Course is in Major & $0.016(0.333)$ & & Course is in Major & $\begin{array}{l}0.417 \\
(0.529)\end{array}$ & \\
\hline Course is in the Core & $0.151(0.280)$ & & $\begin{array}{l}\text { Course is in the } \\
\text { Core }\end{array}$ & $\begin{array}{l}0.222 \\
(0.432)\end{array}$ & \\
\hline Interest in Course & $\begin{array}{l}0.619^{* * *} \\
(0.136)\end{array}$ & 1.857 & Interest in Course & $\begin{array}{l}0.972^{* * *} \\
(0.214)\end{array}$ & 2.645 \\
\hline $\begin{array}{l}\text { Instructor } \\
\text { Communicates } \\
\text { Effectively }\end{array}$ & $\begin{array}{l}2.346 * * * \\
(0.169)\end{array}$ & 10.449 & $\begin{array}{l}\text { Instructor } \\
\text { Communicates } \\
\text { Effectively }\end{array}$ & $\begin{array}{l}2.377^{* * *} \\
(0.252)\end{array}$ & 10.774 \\
\hline
\end{tabular}




\begin{tabular}{|l|l|l|l|l|l|}
\hline $\begin{array}{l}\text { Instructor is the Most } \\
\text { Important Factor }\end{array}$ & $\begin{array}{l}0.717^{* *} \\
(0.283)\end{array}$ & 2.049 & $\begin{array}{l}\text { Instructor is the } \\
\text { Most Important } \\
\text { Factor }\end{array}$ & $\begin{array}{l}0.173 \\
(0.431)\end{array}$ & \\
\hline Year in College & $-0.100(0.122)$ & & Year in College & $\begin{array}{l}-0.255 \\
(0.196)\end{array}$ & \\
\hline Female & $-0.093(0.121)$ & & Female & $\begin{array}{l}-0.086 \\
(0.494)\end{array}$ & \\
\hline Nonwhite & $-0.229(0.297)$ & & Nonwhite & $\begin{array}{l}-1.168^{*} \\
(0.464)\end{array}$ & 0.311 \\
\hline Age & $-0.011(0.014)$ & & Age & $\begin{array}{l}-0.006 \\
(0.018)\end{array}$ & \\
\hline GPA & $-0.983^{* * *}$ & 0.374 & GPA & $\begin{array}{l}-1.059 * * * \\
(0.510)\end{array}$ & 0.202 \\
\hline Constant & $(0.344)$ & & & -9.904 & \\
& -11.553 & & Constant & $(1.886)$ & \\
\hline $\mathrm{N}$ & $(1.422)$ & & & 436 & \\
\hline Pseudo R2 & 967 & & $\mathrm{~N}$ & 0.706 & \\
\hline
\end{tabular}

Two important differences appear in Table 5. First, in support of Hypothesis 2, the variable for the instructor as the most important factor was significant for the face-to-face model but not for the online model, indicating the instructors were more important for face-to-face classes. The major difference we noted as key to lower retention rates in online classes- the distance between instructor and student created by the electronic barrier-came through in these data. A second, and unanticipated, difference was that nonwhite students are significantly less likely to designate an online class as the best class, but ethnicity was not significant in the faceto-face model. This indicates that minority students, which comprise $45 \%$ of the student population at [university redacted] (Quick Facts 2019), may not be as well-served by online classes (Jaggars 2014).

The odds ratios again indicated how important communication is for both online and face-to-face classes, but they also indicate that a student's personal interest in the topic of a course was even more important for online classes. We know from the literature that students who succeed in online classes are those who are more self-motivated (Fryer and Bovee 2016), so a personal interest likely reinforced that success and correlated with the selection of a course as the best. This relationship was stronger for online courses when compared to face-to-face courses.

\section{Qualitative Data}

We can better understand the student experience in both online and face-to-face classes by looking at their open-ended responses to the question "What makes this class the [best/worst] one you have taken at [university redacted]?” Approximately 92\% of survey respondents answered this open-ended question $(\mathrm{n}=1,851)$ and we coded each sentence fragment to capture each unique idea about the class the student communicated $(n=4,096)$. 


\section{Best Classes}

The main qualities that students emphasized as important in the best classes as summarized in Table 6, with online classes in the first column and face-to-face classes in the second column.

Table 6. Categories of responses regarding what makes a class the best, by course modality, summarized from open-ended survey responses

\begin{tabular}{|l|c|l|c|}
\hline Online & $\mathbf{\%}$ & Face-to-Face & $\mathbf{\%}$ \\
\hline $\begin{array}{l}\text { The online modality was less distracting } \\
\text { or better. }\end{array}$ & 15 & $\begin{array}{l}\text { The class included interactive or } \\
\text { project-based learning. }\end{array}$ & 14 \\
\hline $\begin{array}{l}\text { The instructor provided clear } \\
\text { instructions and expectations. }\end{array}$ & 14 & $\begin{array}{l}\text { The class included interesting } \\
\text { discussions }\end{array}$ & 11 \\
\hline $\begin{array}{l}\text { The class included interactive or } \\
\text { project-based learning }\end{array}$ & 11 & $\begin{array}{l}\text { Instructor was engaged and } \\
\text { enthusiastic. }\end{array}$ & 11 \\
\hline The instructor was available. & 11 & $\begin{array}{l}\text { The course provided real-world } \\
\text { experience. }\end{array}$ & 9 \\
\hline The instructor/class was organized. & 11 & The instructor was caring. & 9 \\
\hline Instructor replied to inquiries promptly. & 10 & $\begin{array}{l}\text { The instructor provided clear } \\
\text { instructions and expectations. }\end{array}$ & 8 \\
\hline $\begin{array}{l}\text { The course provided real-world } \\
\text { experience. }\end{array}$ & 9 & The instructor is knowledgeable. & \\
\hline $\begin{array}{l}\text { The information was useful and/or } \\
\text { interesting. }\end{array}$ & 9 & & \\
\hline $\begin{array}{l}\text { The course included consistent } \\
\text { deadlines. }\end{array}$ & 8 & & \\
\hline
\end{tabular}

The qualitative data indicated that students found relevant content that was clearly explained important in both face-to-face and online courses. Students wanted to have information that they feel would be beneficial to their careers and lives, and they wanted faculty to explain it well and assess it fairly with assessments that evaluated their knowledge of the content covered in the class. Regardless of modality, students found clear instructional communication and relevant, well-designed courses (aligned course outcomes, lectures, assignments, and tests) key in their satisfaction with courses. Students wanted faculty who explain materials clearly and take the time to talk them through course assignments.

In the best face-to-face classes, students indicated that a variety of engaging, interactive assignments was an important feature. Students described these projects as "project-based learning," “in-class practice,” "hands-on,” “guest speakers,” “field trips," "labs,” or "writing assignments." Students in both modalities wanted content that prepared them for their future careers and was relevant and practical. Students indicated that the best face-to-face classes described this content as practical, current, or relevant, having real-world application to their future career experiences. Instructor and classroom organization was important in online classes when compared to face-to-face classes, as were instructors who responded in a timely manner, particularly to student email requests. The best online courses allowed students to work around their schedule and contained efficient, useful information. Online students valued courses that 
were consistent and stayed on track with no surprises and clearly expressed due dates that were available immediately.

Instructor enthusiasm or caring similarly important in face-to-face classes and online classes. The best instructors were clearly interested by and knowledgeable about their subject areas. In face-to-face classes, students described the instructors of the best classes using words like kind, caring, nice, friendly, and polite. Students in the best face-to-face classes indicated that good instructors were enthusiastic, dynamic, energetic, and passionate. Interestingly, instructor attitude was not as important online as was attentiveness, timeliness, and clarity of communication. Online students were more likely to identify good instructors as available rather than caring.

\section{Worst Classes}

Sixty-two percent of students completing the worst class survey identified a face-to-face class as their worst class, and 38\% identified an online class as their worst class, as noted in Table 7. Instructor availability in online and face-to-face classes showed a much greater gap than any other area. Thirty-five percent of open-ended responses mentioned instructor communication as a problem in online classes, whereas only $10 \%$ of open-ended responses for the worst face-to-face classes mentioned instructor availability.

Table 7

Categories of responses regarding what makes a class the worst, by course modality, summarized from open-ended survey responses

\begin{tabular}{|l|l|l|l|}
\hline Online & $\mathbf{\%}$ & Face-to-face & $\%$ \\
\hline $\begin{array}{l}\text { The instructor was unavailable or } \\
\text { unresponsive. }\end{array}$ & 35 & $\begin{array}{l}\text { The instructor provided little } \\
\text { instruction on assignments and } \\
\text { activities. }\end{array}$ & 14 \\
\hline $\begin{array}{l}\text { The instructor was unclear about } \\
\text { expectations and the purpose of } \\
\text { assignments. }\end{array}$ & 14 & $\begin{array}{l}\text { The class did not teach anything } \\
\text { worthwhile and/or was a waste of time } \\
\text { and money. }\end{array}$ & 13 \\
\hline $\begin{array}{l}\text { The class was too difficult and/or the } \\
\text { workload was too demanding. }\end{array}$ & 14 & $\begin{array}{l}\text { The instructor was belittling and/or } \\
\text { talked down to students in the class. }\end{array}$ & 13 \\
\hline $\begin{array}{l}\text { The instructor graded unfairly or } \\
\text { subjectively. }\end{array}$ & 10 & $\begin{array}{l}\text { The instructor gave lectures that were } \\
\text { boring and/or lectures were the primary } \\
\text { instruction in the class. }\end{array}$ & 13 \\
\hline $\begin{array}{l}\text { The class did not teach anything } \\
\text { worthwhile and/or was a waste of time } \\
\text { and money. }\end{array}$ & 9 & $\begin{array}{l}\text { The instructor was unavailable or } \\
\text { unresponsive. }\end{array}$ & 10 \\
\hline $\begin{array}{l}\text { The class assignments and exams did } \\
\text { not align or cover the same content as } \\
\text { the instructional materials for the } \\
\text { course. }\end{array}$ & 8 & The instructor was unfair or inflexible. & 10 \\
\hline & & $\begin{array}{l}\text { The class assignments and exams did } \\
\text { not align or cover the same content as } \\
\text { the instructional materials for the } \\
\text { course. }\end{array}$ & 9 \\
\hline The instructor was unorganized. & 8 \\
\hline
\end{tabular}


Poor instructor communication was the single most important factor for either a best or worst class. In the worst classes, both face-to-face and online students found that the worst faculty were unapproachable, unwilling to be questioned, absent, and unresponsive.

In many ways, the qualitative results of student-identified "worst" classes mirrored those of the student-identified "best” classes. Regardless of modality, students' primary concerns were that the classes were a waste of time that did not teach anything worthwhile. Students were frustrated when classes lacked instruction, they felt they were teaching themselves, and/or if the content seemed totally unrelated to the course. Some students remarked that instructors in their worst classes expected them to already know content or assumed relevant content would be covered later in the program.

Poor course design was also a frequent concern of students regardless of modality. Students commented that worst classes included assignments and exams that did not align with course objectives. They did not feel adequately prepared for assessments and felt that they weren't given adequate preparation with shorter homework before large-stakes assessments. They felt the instructor was unfair or inflexible, and that tests were "impossible" to pass. Students said that in the worst classes, the point systems did not make sense.

Perhaps the most striking comments regarding the worst classes were about the instructor of the course. These results reinforced the quantitative answers to the survey. Students in the worst face-to-face classes indicated that the worst instructors wouldn't answer questions or let students ask question. They were unavailable, didn't answer emails, and were described as "unresponsive" or "unapproachable." In the worst online classes, students indicated that there was no instructor interaction; the instructor uploaded everything and "disappeared." The worst online classes lacked instructor lectures and discussion. These courses primarily consisted of reading textbooks and taking tests. Poor online instructors had poor or absent email responses or limited their communication only to the course learning system. Students indicated that getting clarification for instructions and communicating with online faculty was difficult when they would infrequently respond to email.

Instructor availability in online and face-to-face classes showed a much greater gap than any other area. Thirty-five percent of open-ended responses mentioned instructor communication as a problem in online classes, whereas only $10 \%$ of open-ended responses for the worst face-to-face classes mentioned instructor availability. Poor instructor communication was the single most important factor for either a best or worst class. In the worst classes, both face-to-face and online students found that the worst faculty were unapproachable, unwilling to be questioned, absent, and unresponsive.

Students in the worst face-to-face classes indicated that instructors in those classes were more likely to be openly offensive or belittling than teachers in online classes. The worst faceto-face faculty were described using terms like "sarcastic," "rude," "belittling," "defensive” "bigoted and/or racist." Students claimed that bad instructors talked down to class or were openly hostile. The instructors in these classes were "boring," and lectures went "by the book." The instructors in the worst face-to-face classes had little discussion, gave memorized lectures, or were unorganized.

In the worst online classes, students indicated that the instructor was unclear or confusing about expectations. Assignments in the worst online classes seemed irrelevant or random. Students in the worst online classes were also more likely to say that the class was difficult or that the workload was too hard or had too much reading. Assignments were seen as online busywork and/or out of line with the number of class hours. 


\section{Conclusion}

In a changing higher education environment, students are taking - and faculty are teaching - both online and face-to-face classes. Although there are clear differences across these instructional modes, there is much we can learn by asking students about their best and worst experiences with both online and face-to-face classes. By doing so, we learned that the best online and face-to-face classes had many things in common. In both course formats, students appreciate instructors who are engaged and available. Students note caring (or its lack) more when they have personal contact with instructors through face-to-face classes, but overall, instructors matter to students in both online and face-to-face classes. These findings indicate that instructors in both online and face-to-face classes can improve their courses by being available and supportive and by communicating clearly with their students.

There are some key points of difference across formats which are instructive to note. For instance, assignments seem to matter more than instructors in online classes. Students in the worst face-to-face classes are significantly more likely to say the instructor matters the most in their evaluation of the course, whereas students in the worst online classes say assignments matter the most. However, both the quantitative and qualitative data indicated that effective communication was key to the best courses. While student retention and success in any class is the result of a variety of factors, effective instructors and clearly delivered instruction matter a great deal to student success.

In line with our theoretical expectations, instructors in face-to-face classes seem to connect more easily with students in face-to-face classes. Their students notice that relationship and the instructor's attitude and it significantly influences their evaluation of the course. In online classes, on the other hand, personal interactions are less common by definition. Assignments and course organization thus become more important and weigh more heavily as students evaluate the course. In some ways, the instruction stands in for the instructor in an online course, making clear and consistent course materials even more important in online classes. If online instructors are more purposeful in reaching out to and connecting with students and pay particular attention to their communication with students, they may find that students respond positively.

Our data indicates that instructor caring and enthusiasm mattered more for face-to-face students. They were also significantly more likely to rank their relationship with the instructor and the instructor's attitude as more important in their choice of the class as the best. Positive engagement doesn't prompt a student to choose an online classes as the best over a face-to-face class, but a lack of instructor engagement seems to hurt the worst online classes more than it hurts the worst face-to-face classes. In short, online classes are not inherently worse than faceto-face classes or harder for students to like. In either modality, students want information that they feel will be beneficial to their careers and lives, and they want faculty to explain it well and assess it fairly.

Instructors seeking to improve their teaching, either online or in face-to-face courses, will find much to mine from the results here. For instance, the clarity of instruction that is required when electronic communication is primary is also appreciated by face-to-face students. Instructors in face-to-face courses may tend to rely on the ability to clarify assignment instructions in class. Students will likely appreciate the additional effort to write clear instructions into the assignment itself. 
The data also shows that face-to-face students respond positively to instructors who demonstrate engagement and caring. This is much harder to do online, but research indicates that building rapport and relationships with students in online classes can improve their retention and success (Glader 2013, Glazier 2016). One student's open-ended comments exemplified how engagement and caring in online courses matter: "The encouragement from my instructor helped me decide to stay in grad school. She told me that I have good writing skills and encouraged me to do research and continue to grow and develop my skills. The interaction I with the instructor of the other class I was taking that semester was not positive and it really made me question if I was smart enough to be in school.” When instructors are caring and engaged, students notice.

The next step in this research will be to further identify what students see as engagement, caring, enthusiasm, and availability on online classes. Are these specific actions and messages that instructors can learn and try to convey? Or are they more of an abstract feeling? Instructors and instructions matter for both online and face-to-face classes, and instructors have an opportunity to make a positive impact on student retention and success by being available for and communicating clearly with their students.

Acknowledgements:

This research did not receive any specific grant from funding agencies in the public, commercial, or not-for-profit sectors. 


\section{Appendix}

Table A1. Survey Question Wording and Descriptive Statistics

\begin{tabular}{|c|c|c|}
\hline Question Wording & Coding & Descriptive Statistics \\
\hline $\begin{array}{l}\text { Please rank the following four } \\
\text { factors on their contribution to } \\
\text { making this the } \\
\text { [BEST/WORST] class: Your } \\
\text { instructor's relationship with } \\
\text { you (for example: respect, } \\
\text { understanding, annoyance) }\end{array}$ & $\begin{array}{l}\text { Responses coded } 1 \text { to } 4 \text { with } \\
\text { numbers closer to one } \\
\text { indicating that the factor is } \\
\text { ranked as more important. }\end{array}$ & $\begin{array}{l}\text { Range: } 0 \text { to } 4 \\
\text { Mean: } 2.75 \\
\text { S.D.: } 1.06 \\
\text { N: } 1615\end{array}$ \\
\hline $\begin{array}{l}\text { Please rank the following four } \\
\text { factors on their contribution to } \\
\text { making this the } \\
\text { [BEST/WORST] class: Your } \\
\text { instructor's attitude about the } \\
\text { course (for example: } \\
\text { enthusiasm, positivity, the way } \\
\text { teaching responsibilities were } \\
\text { prioritized) }\end{array}$ & $\begin{array}{l}\text { Responses coded } 1 \text { to } 4 \text { with } \\
\text { numbers closer to one } \\
\text { indicating that the factor is } \\
\text { ranked as more important. }\end{array}$ & $\begin{array}{l}\text { Range: } 0 \text { to } 4 \\
\text { Mean: } 2.23 \\
\text { S.D.: } 1.08 \\
\text { N: } 1615\end{array}$ \\
\hline $\begin{array}{l}\text { Please rank the following four } \\
\text { factors on their contribution to } \\
\text { making this the } \\
\text { [BEST/WORST] class: Your } \\
\text { instructor's engagement with } \\
\text { you (for example: response } \\
\text { time, feedback, participation in } \\
\text { class) }\end{array}$ & $\begin{array}{l}\text { Responses coded } 1 \text { to } 4 \text { with } \\
\text { numbers closer to one } \\
\text { indicating that the factor is } \\
\text { ranked as more important. }\end{array}$ & $\begin{array}{l}\text { Range: } 0 \text { to } 4 \\
\text { Mean: } 2.35 \\
\text { S.D.: } 0.98 \\
\text { N: } 1615\end{array}$ \\
\hline $\begin{array}{l}\text { Please rank the following four } \\
\text { factors on their contribution to } \\
\text { making this the } \\
\text { [BEST/WORST] class: Course } \\
\text { organization (for example: } \\
\text { syllabus, due dates, } \\
\text { assignments) }\end{array}$ & $\begin{array}{l}\text { Responses coded } 1 \text { to } 4 \text { with } \\
\text { numbers closer to one } \\
\text { indicating that the factor is } \\
\text { ranked as more important. }\end{array}$ & $\begin{array}{l}\text { Range: } 0 \text { to } 4 \\
\text { Mean: } 2.65 \\
\text { S.D.: } 1.24 \\
\text { N: } 1615\end{array}$ \\
\hline $\begin{array}{l}\text { Whenever you have an issue, } \\
\text { how often is the instructor } \\
\text { available to you? Questions } \\
\text { asked for in-person, in video } \\
\text { conference, on the phone, and } \\
\text { through email availability. }\end{array}$ & $\begin{array}{l}\text { Response options are } \\
\text { always, sometimes, rarely, } \\
\text { and never, with higher } \\
\text { numbers indicating more } \\
\text { availability. All four are } \\
\text { summed into a single } \\
\text { measure of availability. } \\
\end{array}$ & $\begin{array}{l}\text { Range: } 4 \text { to } 16 \\
\text { Mean: } 11.92 \\
\text { S.D.: } 3.59 \\
\text { N: } 339\end{array}$ \\
\hline $\begin{array}{l}\text { To what extent does the } \\
\text { instructor effectively } \\
\text { communicate with you? }\end{array}$ & $\begin{array}{l}\text { Response options from } 1 \text { to } \\
5 \text { with higher numbers } \\
\text { indicating more effective } \\
\text { communication. }\end{array}$ & $\begin{array}{l}\text { Range: } 1 \text { to } 5 \\
\text { Mean: } 3.65 \\
\text { S.D.: } 1.34 \\
\text { N: } 1800 \\
\end{array}$ \\
\hline
\end{tabular}




\begin{tabular}{|c|c|c|}
\hline $\begin{array}{l}\text { What reason contributed the } \\
\text { MOST to this course being the } \\
\text { [BEST/WORST] class you have } \\
\text { taken at UNIVERSITY? My } \\
\text { interest in the subject }\end{array}$ & $\begin{array}{l}\text { Each option is treated as a } \\
\text { dummy variable and coded } 1 \\
\text { if it is selected and } 0 \text { if it is } \\
\text { not. }\end{array}$ & $\begin{array}{l}\text { Range: } 0 \text { to } 1 \\
\text { Mean: } 0.109 \\
\text { S.D.: } 0.312 \\
\text { N: } 2007\end{array}$ \\
\hline $\begin{array}{l}\text { What reason contributed the } \\
\text { MOST to this course being the } \\
\text { [BEST/WORST] class you have } \\
\text { taken at UNIVERSITY? The } \\
\text { instructor. }\end{array}$ & $\begin{array}{l}\text { Each option is treated as a } \\
\text { dummy variable and coded } 1 \\
\text { if it is selected and } 0 \text { if it is } \\
\text { not. }\end{array}$ & $\begin{array}{l}\text { Range: } 0 \text { to } 1 \\
\text { Mean: } 0.593 \\
\text { S.D.: } 0.491 \\
\text { N: } 2007\end{array}$ \\
\hline $\begin{array}{l}\text { What reason contributed the } \\
\text { MOST to this course being the } \\
\text { [BEST/WORST] class you have } \\
\text { taken at UNIVERSITY? } \\
\text { Assignments/readings/activities; }\end{array}$ & $\begin{array}{l}\text { Each option is treated as a } \\
\text { dummy variable and coded } 1 \\
\text { if it is selected and } 0 \text { if it is } \\
\text { not. }\end{array}$ & $\begin{array}{l}\text { Range: } 0 \text { to } 1 \\
\text { Mean: } 0.213 \\
\text { S.D.: } 0.409 \\
\text { N: } 2007\end{array}$ \\
\hline $\begin{array}{l}\text { What reason contributed the } \\
\text { MOST to this course being the } \\
\text { [BEST/WORST] class you have } \\
\text { taken at UNIVERSITY? My } \\
\text { personal circumstances at the } \\
\text { time I took the class. }\end{array}$ & $\begin{array}{l}\text { Each option is treated as a } \\
\text { dummy variable and coded } 1 \\
\text { if it is selected and } 0 \text { if it is } \\
\text { not. }\end{array}$ & $\begin{array}{l}\text { Range: } 0 \text { to } 1 \\
\text { Mean: } 0.032 \\
\text { S.D.: } 0.177 \\
\text { N: } 2007\end{array}$ \\
\hline GPA & & $\begin{array}{l}\text { Range: } 1.3 \text { to } 4 \\
\text { Mean: } 3.464 \\
\text { S.D.: } 0.466 \\
\text { N: } 1758\end{array}$ \\
\hline Year in College & & $\begin{array}{l}\text { First Year: } 190 \\
\text { Sophomore: } 279 \\
\text { Junior: } 425 \\
\text { Senior: } 553 \\
\text { Graduate: } 433\end{array}$ \\
\hline Year Born & & $\begin{array}{l}\text { Range: } 1920 \text { to } 2000 \\
\text { Mean: } 1988 \\
\text { S.D.: } 11.04 \\
\text { N: } 1762\end{array}$ \\
\hline Race/Ethnicity & & $\begin{array}{l}\text { White: 1,205 (63.6\%) } \\
\text { Black: } 389(20.5 \%) \\
\text { Hispanic or Latino/a: } 100 \\
\text { (5.3\%) } \\
\text { Asian: } 116(6.1 \%) \\
\text { Native American or Pacific } \\
\text { Islander: } 19(1 \%) \\
\text { Other: } 64(3.4 \%)\end{array}$ \\
\hline Gender & & $\begin{array}{l}\text { Female: } 1,335(70.1 \%) \\
\text { Male: } 551(28.9 \%) \\
\text { Other: } 18(0.09 \%)\end{array}$ \\
\hline
\end{tabular}


Works Cited

Allen, I. Elaine, and Jeff Seaman. 2017. Digital Compass Learning: Distance Education Enrollment Report 2017. In Babson Survey Research Group.

Aquila, Meredith Suzanne Hahn. 2017. "Building the Personal: Instructors' Perspectives of Rapport in Online and Face-to-Face Classes." Doctor of Arts Community College Education, George Mason University.

Bolsen, Toby, Michael Evans, and Anna McCaghren Fleming. 2016. "A Comparison of Online and Face-to-Face Approaches to Teaching Introduction to American Government." Journal of Political Science Education 12 (3):302-317. doi: 10.1080/15512169.2015.1090905.

Bowers, James, and Poonam Kumar. 2015. "Students' perceptions of teaching and social presence: A comparative analysis of face-to-face and online learning environments." International Journal of Web-Based Learning and Teaching Technologies 10 (1):27-44.

Capra, Theresa. 2011. "Online education: Promise and problems." Journal of Online Learning and Teaching 7 (2):288-293.

Carr-Chellman, Alison, and Philip Duchastel. 2000. "The Ideal Online Course." British Journal of Educational Technology 31 (3):229-241.

Chen, P.D., Kevin R. Guidry, and Amber D. Lambert. 2009. "Engaging online learners: A quantitative study of postsecondary student engagement in the online learning environment." Annual meeting of the American Educational Research Association, San Diego, CA.

Chingos, Matthew M., Rebecca J. Griffiths, Christine Mulhern, and Richard R. Spies. 2017. "Interactive online learning on campus: Comparing students’ outcomes in hybrid and traditional courses in the university system of maryland." The Journal of Higher Education 88 (2):210-233.

Fryer, Luke K., and H. Nicholas Bovee. 2016. "Supporting students' motivation for e-learning: Teachers matter on and offline." The Internet and Higher Education 30:21-29.

Glader, Paul. 2013. "Dropout Redemption: Online Courses Can Increase College Graduation Rates." Forbes.

Glazier, Rebecca A. 2016. "Building rapport to improve retention and success in online classes." Journal of Political Science Education 12 (4):437-456.

Glazier, Rebecca A., Kerstin Hamann, Philip H. Pollock, and Bruce M. Wilson. 2019. "Age, Gender, and Student Success: Mixing Face-to-Face and Online Courses in Political Science." Journal of Political Science Education Published Online March 20, 2019:1-16. doi: 10.1080/15512169.2018.1515636.

Jaggars, Shanna Smith. 2014. "Choosing between online and face-to-face courses: Community college student voices." American Journal of Distance Education 28 (1):27-38.

Kanasa, Harry. 2017. "Establishing and maintaining rapport in an online, higher education setting." In Student Engagement and Educational Rapport in Higher Education, edited by L. Rowan and P. Grootenboer, 67-85. New York: Springer.

Kupczynski, Lori, Phil Ice, Randy Wiesenmayer, and Frank McCluskey. 2010. "Student perceptions of the relationship between indicators of teaching presence and success in online courses." Journal of Interactive Online Learning 9 (1). 
Lammers, William J., and J. Arthur Gillaspy Jr. 2013. "Brief measure of student-instructor rapport predicts student success in online courses." International Journal for the Scholarship of Teaching and Learning 7 (2):16.

Lederman, Doug. 2018. "Who is studying online (and where)." Inside Higher Ed 5.

Levy, Yair. 2007. "Comparing Dropouts and Persistence in E-Learning Courses." Computers \& Education 48 (2):185-204.

Magda, Andrew J., Russell Poulin, and D.L. Clinefelter. 2015. Recruiting, orienting, \& supporting online adjunct faculty: A survey of practices. Louisville, KY: The Learning House.

McLaren, Constance H. 2004. "A Comparison of Student Persistence and Performance in Online and Classroom Business Statistics Experiences." Decision Sciences Journal of Innovative Education 2 (1):1-10. doi: 10.1111/j.0011-7315.2004.00015.x.

Moore, Michael G. 2013. "The theory of transactional distance." In Handbook of distance education, edited by Michael G. Moore. New York: Routledge.

Murphy, Cheryl A., and John C. Stewart. 2017. "On-campus students taking online courses: Factors associated with unsuccessful course completion." The Internet and Higher Education 34:1-9.

Murphy, Elizabeth, and María A Rodríguez-Manzanares. 2012. "Rapport in Distance Education." The International Review of Research in Open and Distance Learning 13 (1):167-190.

Ortagus, Justin C. 2017. "From the periphery to prominence: An examination of the changing profile of online students in American higher education." The Internet and Higher Education 32:47-57. doi: http://dx.doi.org/10.1016/j.iheduc.2016.09.002.

Patterson, Belinda, and Cheryl McFadden. 2009. "Attrition in Online and Campus Degree Programs." Online Journal of Distance Learning Administration 12 (2).

Preisman, Kristi A. 2014. "Teaching Presence in Online Education: From the Instructor's Point of View." Online Learning 18 (3):n3.

Quick Facts. 2019. "University of Arkansas at Little Rock." accessed July 15. https://ualr.edu/administration/fast-facts/.

Seaman, Julia E., I. Elaine Allen, and Jeff Seaman. 2018. Grade Increase: Tracking Distance Education in the United States. In Babson Survey Research Group.

Sher, Ali. 2009. "Assessing the relationship of student-instructor and student-student interaction to student learning and satisfaction in web-based online learning environment." Journal of Interactive Online Learning 8 (2).

Skurat Harris, H., L. Meloncon, B. Hewett, M.X. Mechenbier, and D. Martinez. 2019. "A call for a purposeful pedagogy-driven course design in OWI." Research in Online Literacy Education 2 (1).

Snyder, Thomas D., Cristobal de Brey, and Sally A. Dillow. 2019. Digest of Education Statistics 2017 (NCES 2018-070). Washington, DC. : National Center for Education Statistics, Institute of Education Sciences, U.S. Department of Education.

Strauss, A.L., and J.M. Corbin. 1998. Basics of qualitative research: Grounded theory procedures and techniques. 2nd ed. Thousand Oaks, CA: Sage.

Tello, Steven F. 2007. "An Analysis of Student Persistence in Online Education." International Journal of Information and Communication Technology Education 3 (3):47-62.

Worley, Wanda L., and Lee S. Tesdell. 2009. "Instructor time and effort in online and face-toface teaching: Lessons learned." IEEE Transactions on Professional Communication 52 (2):138-151. 
